\title{
Peningkatan hasil belajar pembagian pecahan biasa dengan pendekatan konstruktivisme
}

\section{Badriyah Badriyah}

SDN 08 Lunang Kecamatan Lunang

\begin{tabular}{l} 
Article Info \\
\hline Article history: \\
Received Jul $18^{\text {th }}, 2020$ \\
Revised Aug $29^{\mathrm{h}}, 2020$ \\
Accepted Sep $30^{\text {th }}, 2020$ \\
\hline
\end{tabular}

\section{Keyword:}

Hasil belajar

Pembagian pecahan biasa

Pendekatan konstruktivisme

\begin{abstract}
Jenis penelitian adalah Penelitian Tindakan Kelas menggunakan pendekatan kualitatif dan kuantitatif. Subjek penelitian guru dan 21 siswa kelas VI. Teknik pengumpulan data menggunakan observasi, tes, dokumentasi. Analisis data menggunakan analisis data kualitatif yaitu reduksi data, penyajian data, kesimpulan. Analisis data kuantitatif yaitu analisis deskriptif. Penelitian dilaksanakan II siklus. Setiap siklus terdiri dari perencanaan, pelaksanaan, pengamatan, refleksi.Hasil penelitian menunjukkan peningkatan dari siklus I ke siklus II, perencanaan pembelajaran dari 71,43\% (baik) menjadi 89,29\% (sangat baik). Aktivitas guru dari 67,5\% (cukup) menjadi 87,5\% (sangat baik), aktivitas siswa dari 68,75\% (cukup) menjadi 87,5\% (sangat baik). Hasil belajar aspek kognitif siswa dari 66,13 (cukup) menjadi 81,02 (sangat baik), afektif dari 60,41 (cukup) menjadi 80,45 (sangat baik), psikomotor dari 59,46 (kurang) menjadi 81,44 (sangat baik). Dapat disimpulkan bahwa pendekatan konstruktivisme dapat meningkatkan hasil belajar pembagian pecahan biasa di kelas VI UPT SDN 08 Lunang Kabupaten Pesisir Selatan.
\end{abstract}

(C) 2020 The Authors. Published by IICET.

This is an open access article under the CC BY-NC-SA license

(https://creativecommons.org/licenses/by-nc-sa/4.0

\section{Corresponding Author:}

Badriyah Badriyah,

SDN 08 Lunang Kecamatan Lunang

Email: badriyah@gmail.com

\section{Pendahuluan}

Dalam kehidupan sehari-hari siswa juga ditemui permasalahan yang berhubungan dengan konsep pembagian pecahan biasa. Contohnya, Ibu mempunyai $2 \mathrm{~kg}$ gula yang akan dibuat kue. Masing-masing resep kue memerlukan $\frac{1}{4} \mathrm{~kg}$ gula. Berapa banyak resep yang dapat dibuat ibu? Kemudian, jika masing-masing resep memerlukan gula $\frac{3}{4} \mathrm{~kg}$, berapa banyak resep kue yang dapat dibuat ibu?

Berdasarkan temuan peneliti dalam pembelajaran pembagian pecahan biasa di kelas VI UPT SDN 08 Lunang Kecamatan Lunang Kabupaten Pesisir ternyata ada beberapa permasalahan pada pembelajaran Pembagian Pecahan Biasa, yaitu 1) guru masih banyak menggunakan metode ceramah dalam proses pembelajaran, 2) siswa tidak memiliki kesempatan untuk mengemukakan pengetahuannya karena dalam pembelajaran siswa langsung menerima konsep dari guru, 3) siswa tidak memiliki kesempatan untuk berpikir secara maksimal untuk membangun pemahaman tentang konsep baru, dan 4) dalam mengaplikasikan pemahamannya mengenai konsep baru siswa hanya meniru contoh yang dipaparkan guru di papan tulis sehingga pemahaman siswa hanya bersifat tekstual. 
Berdasarkan permasalahan yang telah dikemukakan di atas, peneliti tertarik untuk memperbaiki proses pembelajaran pembagian pecahan biasa melalui penelitian tindakan kelas dengan judul "Peningkatan Hasil Belajar Pembagian Pecahan Biasa dengan Pendekatan Konstruktivisme di Kelas VI UPT SDN 08 Lunang Kecamatan Lunang Kabupaten Pesisir Selatan".

\section{Metode}

Penelitian ini dilaksanakan di UPT SDN 08 Lunang Kecamatan Lunang dengan subjek penelitian yaitu siswa kelas VI yang berjumlah 21 orang. Yang terdiri dari 10 orang laki-laki dan 11 orang perempuan. Penelitian ini dilaksanakan pada semester genap Januari - Juni 2019. Penelitian dilakukan dalam II siklus. Siklus I pertemuan 1 pada hari Rabu tanggal 24 April 2019, pertemuan 2 pada hari Jumat tanggal 26 April 2019, sedangkan siklus II pertemuan 1 pada hari Rabu tanggal 1 Mei 2019.

Pendekatan yang digunakan dalam proses penelitian adalah pendekatan kualitatif dan kuantitatif. Seperti yang dinyatakan Wijaya (2009:9) bahwa "Penelitian Tindakan Kelas termasuk penelitian kualitatif walaupun data yang dikumpulkan bisa saja bersifat kuantitatif."

Jenis penelitian ini adalah penelitian tindakan kelas di bidang pendidikan dengan materi pembagian pecahan biasa biasa. Penelitian ini berkenaan dengan perbaikan atau peningkatan proses pembelajaran pembagian pecahan biasa dalam kelas, yang didasarkan pada masalah-masalah yang ditemukan di lapangan.

Penelitian dilaksanakan menggunakan model siklus yang dikembangkan oleh Kemmis dan Mc Taggart. Menurut Kemmis dan Mc Taggart (dalam Sukajati, 2008:19), "proses penelitian tindakan dipandang sebagai suatu siklus spiral atau proses daur ulang yang dimulai dari penyusunan perencanaan, pelaksanaan tindakan sesuai dengan rencana, pengamatan/observasi terhadap tindakan, dan melakukan refleksi yaitu perenungan terhadap perencanaan, kegiatan tindakan dan keberhasilan hasil yang diperoleh." Prosedur penelitian yang dilakukan yaitu perencanaan, pelaksanaan, pengamatan dan refleksi. Data penelitian berupa hasil pengamatan, dokumentasi, dan tes dari pembelajaran pembagian pecahan biasa pada siswa kelas VI.

Miles dan Huberman (Sugiyono, 2012:338-345) menjelaskan tahap analisis data terdiri atas: 1) Data Reduction (Reduksi Data). Tahap ini meliputi penyeleksian, pemilihan, pengkategorian dan pengklasifikasian data yang diperoleh. Semua data yang telah terkumpul diseleksi dan dikelompokan sesuai dengan penelitian tindakan. Data yang dipisah-pisahkan tersebut kemudian diseleksi mana yang relevan; 2) Data Display (Penyajian Data). Menyajikan data dilakukan dengan cara mengorganisasikan informasi yang sudah direduksi. Data tersebut mula-mula disajikan terpisah, tetapi setelah tindakan terakhir direduksi, keseluruhan data tindakan dirangkum dan disajikan secara terpadu; 3) Conclusion Drawing/Verification (Penarikan Kesimpulan/ Verifikasi). Tindakan ini dilakukan dengan cara peninjauan kembali catatan lapangan, dan bertukar fikiran dengan ahli, teman sejawat, serta guru dan kepala sekolah.

Hasil analisis dari data kualitiatif tersebut kemudian dilakukan analisis kembali menggunakan teknik analisis kuantitatif. Analisis data kuantitatif ini dilakukan terhadap hasil belajar siswa dengan menggunakan Penilaian Acuan Patokan (dalam Aderusliana, 2007:6). Untuk mendapatkan nilai rata-rata kelas dalam masing-masing ranah digunakan rumus pendekatan persentase yang dikemukakan oleh Purwanto (2006:102).

\section{Hasil dan Pembahasan}

\section{Hasil Penelitian \\ Siklus I Pertemuan 1 \\ Perencanaan}

Penerapan pendekatan konstruktivisme dalam pembelajaran pembagian pecahan biasa diwujudkan dalam bentuk rancangan pembelajaran model rencana pelaksanaan pembelajaran (RPP). Rancangan ini disusun sesuai dengan KTSP 2006 kelas VI semester II dengan alokasi 2x35 menit pada pertemuan 1. Dengan standar kompetensi "Menggunakan pecahan dalam pemecahan masalah" dan kompetensi dasar yaitu "Mengalikan dan membagi berbagai bentuk pecahan". Materi yang diambil adalah tentang pembagian pecahan biasa dengan bilangan asli dan sebaliknya.

\section{Pelaksanaan}

Pelaksanaan pembelajaran pembagian pecahan biasa dengan pendekatan konstruktivisme di kelas VI UPT SDN 08 Lunang Kabupaten Pesisir Selatan di semester II Januari-Juli tahun ajaran 2018/2019. Pada siklus I dilakukan sebanyak 2x pertemuan. Pertemuan 1 dilaksanakan pada Rabu, 28 April 2019 mulai pukul 11.03- 
12.15 WIB dengan jumlah 21 siswa. Pembelajaran dilakukan dengan tiga tahap yaitu kegiatan awal, kegiatan inti, dan kegiatan akhir sesuai dengan RPP yang telah dibuat.

\section{Kegiatan Awal}

Kegiatan mengkondisikan kelas, berdo'a, mengabsen siswa, apersepsi tentang pembelajaran sebelumnya, dan menyampaikan tujuan pembelajaran pembagian pecahan biasa dengan bilangan asli dan sebaliknya.

\section{Kegiatan Inti}

Kegiatan inti mencakup Eksplorasi, tahap pertama. Pada tahap ini siswa diberikan kesempatan untuk mengemukakan pengetahuan awal mengenai konsep yang akan dipelajari, Guru menyediakan media berupa lingkaran yang telah dibagi, minuman gelas, dan potongan biskuit.

Elaborasi, tahap kedua. Pada tahap ini siswa akan menemukan konsep baru yang dipelajari. Kegiatannya berupa: a) siswa duduk dalam kelompok belajar yang dibagi guru. b) Siswa mengerjakan soal yang ada pada LKS sesuai dengan petunjuk dan media yang telah disediakan. c) Siswa menggambarkan pada LKS hasil pembagian bilangan asli dengan pecahan biasa yang didapatkan dari penggunaan media, dan d) siswa mendiskusikan hasil kerja mereka di dalam kelompok masing-masing.

Tahap ketiga. Di tahap ini siswa dibimbing membangun sendiri pemahaman baru mereka tentang konsep pembagian bilangan asli dengan pecahan yang dipelajari. Kegiatan yang dilakukan: a) masing-masing perwakilan kelompok melaporkan hasil kerja kelompok yang telah dibuat. b) kelompok lain diberikan kesempatan untuk menanggapi laporan yang disampaikan, dan c) guru berperan sebagai moderator yang mengontrol kelancaran diskusi. Konfirmasi dengan kegiatannya yaitu guru memberikan penguatan terhadap kerja kelompok.

Tahap keempat. Pada tahap ini siswa mengaplikasikan pemahaman dari konsep baru yang telah dibangunnya berupa pemberian contoh soal lain mengenai pembagian bialangan asli dengan pecahan. kegiatan pada tahap ini adalah a) siswa mengerjakan contoh soal lain tentang pembagian bilangan asli dengan pecahan biasa yang diberikan guru, b) siswa dan guru membahas secara bersama contoh soal pembagian bilangan asli dengan pecahan biasa yang diberikan guru, dan c) guru melakukan refleksi berupa tanya jawab bersama siswa mengenai cara meyelesaikan pembagian bilangan asli dengan pecahan biasa.

\section{Kegiatan Akhir}

Pada kegiatan akhir ini, a) siswa dibawah bimbingan guru menyimpulkan materi tentang pembagian bilangan asli dengan pecahan, b) siswa diberikan tindak lajut berupa soal-soal latihan yang harus dikerjakan secara individu.

\section{Pengamatan}

\section{Rencana pelaksanaan pembelajaran}

Dari hasil penilaian RPP diperoleh persentase 89,29 \% dengan kualifikasi sangat baik (SB). Berdasarkan dari hasil tersebut dapat disimpulkan bahwa masih ada beberapa deskriptor yang terdapat pada RPP belum terlaksana. Hal ini berarti perlu dilakukan evaluasi agar dapat meningkatkan hasil perencanaan pada proses berikutnya.

\section{Aktivitas guru selama proses pembelajaran}

Berdasarkan pengamatan ini, dalam pembelajaran yang dilakukan hanya 10 deskriptor yang terlaksana dari total maksimal 16 deskriptor yang telah. Dari penilaian tersebut diperoleh persentase $62,5 \%$ dengan kualifikasi cukup (C). Dengan demikian dapat disimpulkan bahwa dari hasil yang diperoleh, masih perlu diadakan perbaikan dalam mengajar pada pertemuan berikutnya. Untuk lebih jelasnya dapat dilihat pada lampiran.

\section{Aktivitas siswa selama proses pembelajaran}

Berdasarkan pengamatan terhadap aktivitas siswa dalam pembelajaran hanya 10 deskriptor yang terlaksana dari total maksimal 16 deskriptor yang telah. Dari penilaian tersebut diperoleh persentase 62, 5\% dengan kualifikasi cukup (C). Dengan demikian masih perlu diadakan perbaikan pada pertemuan berikutnya agar tercapai tujuan pembelajaran yang telah ditetapkan. Untuk lebih jelasnya dapat dilihat pada lampiran.

\section{Hasil belajar siswa}

Hasil belajar yang akan dicapai dalam pembelajaran pembagian pecahan biasa dengan pendekatan konstruktivisme terbagi menjadi tiga ranah, yaitu: 1) Ranah Kognitif. Dari 21 siswa hanya 9 siswa yang mencapai KKM yang ditentukan dan 12 siswa lainnya masih berada di bawah KKM, dengan skor tertinggi 90 dan skor terendah yang diperoleh siswa 30. Rata-rata nilai yang diperoleh adalah 62,86\% dengan kualifikasi cukup (C); 2) Ranah Afektif. Dari 21 siswa hanya 5 siswa saja yang mencapai KKM yang 
ditentukan dan 16 siswa lainnya masih berada di bawah KKM, dengan skor tertingginya adalah 83,33 dan skor terendahnya 33,33. Rata-rata nilai yang diperoleh adalah 55,16\% dengan kualifikasi kurang (D); 3) Ranah Psikomotor. Dari 21 siswa hanya 5 siswa saja yang mencapai KKM yang ditentukan dan 16 siswa lainnya masih berada di bawah KKM, dengan skor tertingginya adalah 75,33 dan skor terendahnya 33,33. Rata-rata nilai yang diperoleh adalah 58,73\% dengan kualifikasi kurang (D). Berdasarkan hasil belajar pada tiga ranah di atas dapat diketahui bahwa pembelajaran pembagian pecahan biasa dengan pendekatan konstruktivisme pada pertemuan I siklus 1 ini masih banyak kekurangan yang harus diperbaiki agar dapat meningkatkan hasil belajar siswa pada materi pembagian pecahan.

\section{Refleksi}

Proses pembelajaran yang dilaksanakan pada siklus I pertemuan 1 ini difokuskan pada pembelajaran pembagian bilangan asli dengan pecahan biasa menggunakan pendekatan konstruktivisme. Refleksi dilakukan setelah pengamatan dan analisis terhadap pelaksanaan pembelajaran. Analisis tersebut kemudian menghasilkan hal-hal berikut:

\section{Rencana Pelaksanaan Pembelajaran}

Berdasarkan lembar penilaian RPP yang diamati dan dinilai oleh guru kelas VI masih banyak deskriptor yang tidak muncul dalam pembelajaran yaitu: 1) pengorganisasian materi yang diberikan belum luas cakupannya sehingga pada pertemuan selanjutnya guru memperluas cakupan materi yang diberikan; 2) pemilihan sumber/media pembelajaran yang belum sesuai dengan karakteristik siswa dan pada pertemuan selanjutnya guru harus menyesuaikan pemilihan sumber/media pembelajaran dengan karakteristik siswa; 3) kelengkapan instrumen pembelajaran, dimana soal belum dilengkapi dengan pedoman skor yang jelas sehingga selanjutnya guru harus melengkapi instrumen pembelajaran yaitu dengan menyertakan pedoman skor yang jelas dan lengkap pada soal-soal.

\section{Pelaksanaan aktivitas guru}

Aktivitas peneliti sebagai guru praktisi diamati dan dianalisis oleh guru kelas VI serta teman sejawat. Berdasarkan hasil pengamatan dan analisis tersebut ditemukan beberapa hambatan dalam proses pembelajaran, yaitu: 1) pada tahap pertama guru belum menciptakan suasana yang kondusif untuk siswa belajar sehingga pada pertemuan selanjutnya guru harus mampu menciptakan suasana yang kondusif bagi siswa dalam belajarnya; 2) pada tahap kedua guru belum memfasilitasi siswa dalam mengerjakan LKS sehingga pada pertemuan berikutnya guru perlu memfasilitasi siswa dalam mengerjakan LKS-nya; 3) pada tahap ketiga guru belum membantu kelancaran siswa dalam melaporkan hasil kerja mereka serta guru juga belum memberikan penguatan terhadap hasil kerja kelompok dan pada pertemuan berikut seharusnya guru membantu kelancaran siswa dalam menyampaikan laporan terhadap hasil kerja kelompoknya serta memberikan penguatan terhadap hasil kerja kelompok, berupa pujian ataupun masukan yang baik; 4) pada tahap keempat guru belum memberi kesempatan pada siswa untuk menyelesaikan sendiri soal yang diberikan serta guru belum melakukan refleksi kepada siswa berupa tanya jawab mengenai cara menyelesaikan pembagian bilangan asli dengan pecahan biasa sehingga pada pertemuan yang berikut guru harus memberikan kesempatan kepada siswa untuk menyelesaikan sendiri soal-soal tersebut, serta melakukan refleksi terhapa pembelajaran yang telah dilakukan.

\section{Pelaksanaan aktivitas siswa}

Dalam pelaksanaan pembelajaran pembagian pecahan biasa dengan pendekatan konstruktivisme, aktivitas siswa diamati oleh teman sejawat. Pelaksanaan aktivitas siswa dalam pembelajaran masih mengalami kekurangan, yaitu: 1) pada tahap pendahuluan siswa belum mengkomunikasikan pengetahuan awal mereka mengenai pembagian pecahan biasa serta siswa belum aktif dalam menjawab pertanyaan guru. Pada pertemuan selanjutnya guru sebaiknya meningkatkan motivasi siswa agar lebih mengkomunikasikan pengetahuan awalnya tentang pembagian pecahan biasa, dan guru juga perlu lebih memotivasi siswa untuk aktif dalam menjawab pertanyaan guru; 2) Pada tahap kedua siswa belum berkesempatan mengerjakan LKS menggunakan media; 3) Pada tahap ketiga siswa belum mendengarkan penguatan guru terhadap hasil kerja kelompok. Pada pertemuan yang berikutnya guru seharusnya memberikan penguatan terhadap hasil kerja kelompok berupa pujian ataupun masukan; 4) Pada tahap keempat siswa belum menyelesaikan sendiri soal yang diberikan guru serta siswa belum bertanya jawab dengan guru tentang cara melakukan pembagian bilangan asli dengan pecahan biasa.

\section{Hasil belajar siswa}

Hasil belajar siswa ranah kognitif pada siklus I pertemuan 1 masih di bawah nilai KKM yang telah ditetapkan yaitu $62,86 \%$. Pada ranah afektif, banyak siswa yang terlihat masih belum aktif dalam melakukan tanya jawab dengan guru, saat melakukan diskusi sebagian siswa masih belum aktif dalam menemukan penyelesaian LKS, 
dan beberapa siswa kurang menghargai temannya disaat temannya menyampaikan laporannya. Hasil belajar ranah afektif memperoleh rata-rata nilai $55,16 \%$.

Selanjutnya pada ranah psikomotor dapat dilihat bahwa masih banyak siswa yang kesulitan menjawab pertanyaan yang diberikan. Selain itu, sebagian siswa masih mengalami kesulitan dalam membangun pemahaman mengenai konsep baru yang diberikan. Hal ini juga berpengaruh pada kemampuan siswa dalam mengaplikasikan pemahaman baru tersebut dalam bentuk penyelesaian soal-soal. Hasil belajar pada ranah psikomotor ini memperoleh rata-rata 58,73.

Secara keseluruhan diperoleh rata-rata hasil belajar siswa pada siklus I pertemuan 1 ini adalah 60,06. Berdasarkan dari hasil tersebut dapat disimpulkan bahwa pembelajaran pembagian pecahan biasa dengan pendekatan konstruktivisme pada siklus I pertemuan 1 ini masih belum mencapai target yang diharapkan. Oleh sebab itu perlu diadakan tindakan perbaikan pada pertemuan selanjutnya.

\section{Siklus I Pertemuan 2 \\ Perencanaan}

Pembelajaran pada siklus I pertemuan 2 ini difokuskan pada pembagian pecahan biasa dengan bilangan asli. Indikator yang akan dicapai adalah: 1) menyebutkan contoh masalah sehari-hari yang berkaitan dengan pembagian pecahan biasa, 2) menyelesaikan masalah yang berkaitan dengan pembagian pecahan biasa dengan bilangan asli, 3) menjelaskan cara menyelesaikan masalah yang berkaitan pembagian pecahan biasa dengan bilangan asli, dan 4) menyelesaikan soal yang berkaitan dengan pembagian pecahan biasa dengan bilangan asli.

\section{Pelaksanaan}

Pelaksanaan pembelajaran pembagian pecahan biasa dengan pendekatan konstruktivisme di kelas VI UPT SDN 08 Lunang Kabupaten Pesisir Selatan siklus I pertemuan 2 ini dilaksanakan pada Rabu, 30 April 2019 mulai pukul 07.30-08.40 WIB dengan jumlah 21 siswa. teman sejawat sebagai observer. Pembelajaran dilakukan dengan tiga tahap sebagai berikut:

\section{Kegiatan Awal}

Kegiatan mengkondisikan kelas, berdo'a, mengabsen siswa, apersepsi tentang pembelajaran sebelumnya, dan menyampaikan tujuan pembelajaran pembagian pecahan biasa dengan bilangan asli.

\section{Kegiatan Inti}

Kegiatan inti mencakup Eksplorasi, tahap pertama. Pada tahap ini siswa diberikan kesempatan untuk mengemukakan pengetahuan awal mengenai konsep yang akan dipelajari. Elaborasi, tahap kedua. Pada tahap ini siswa akan menemukan konsep baru yang dipelajari. Kegiatannya berupa: a) siswa duduk dalam kelompok belajar yang dibagi guru. b) Siswa mengerjakan soal yang ada pada LKS c) Siswa menggambarkan pada LKS hasil pembagian pecahan biasa dengan bilangan asli yang diperoleh dari penggunaan media, dan d) siswa mendiskusikan hasil kerja mereka di dalam kelompok masing-masing. Tahap ketiga. Di tahap ini siswa dibimbing membangun sendiri pemahaman baru mereka tentang konsep pembagian bilangan asli dengan pecahan yang dipelajari. Konfirmasi dengan kegiatannya yaitu guru memberikan penguatan terhadap kerja kelompok. Dengan adanya penguatan dari guru, siswa dapat memantapkan pemahaman baru mengenai pembagian pecahan biasa dengan bilangan asli yang telah mereka bangun sendiri. Tahap keempat. Pada tahap ini siswa mengaplikasikan pemahaman konsep baru yang telah dibangunnya berupa pemberian contoh soal lain mengenai pembagian pecahan biasa dengan bilangan asli.

\section{Kegiatan Akhir}

Pada kegiatan akhir ini, a) siswa dibawah bimbingan guru menyimpulkan materi tentang pembagian pecahan biasa dengan bilangan asli, b) siswa diberikan tindak lajut berupa soal-soal latihan yang harus dikerjakan secara individu.

\section{Pengamatan}

Hasil pengamatan yang dilakukan observer I dan II dapat dijelaskan sebagai berikut:

\section{Rencana pelaksanaan pembelajaran}

Dari hasil penilaian RPP diperoleh persentase 96,43\% dengan kualifikasi Sangat baik (SB). Berdasarkan dari hasil tersebut dapat disimpulkan bahwa masih ada beberapa deskriptor yang terdapat pada RPP belum terlaksana. Hal ini berarti perlu dilakukan evaluasi agar dapat meningkatkan hasil perencanaan pada proses berikutnya. 


\section{Aktivitas guru selama proses pembelajaran}

Pengamatan aktivitas guru selama proses pembelajaran dilakukan oleh guru kelas $\mathrm{V}$ sebagai observer. Berdasarkan pengamatan ini, dalam pembelajaran yang dilakukan telah terlaksana 12 deskriptor dari total maksimal 16 deskriptor yang telah. Dari penilaian tersebut diperoleh persentase $75 \%$ dengan kualifikasi baik (B). Meskipun demikian masih perlu dilakukan perbaikan pada pertemuan selanjutnya.

\section{Aktivitas siswa selama proses pembelajaran}

Berdasarkan pengamatan terhadap aktivitas siswa dalam pembelajaran hanya 12 deskriptor yang terlaksana dari total maksimal 16 deskriptor yang telah. Dari penilaian tersebut diperoleh persentase $75 \%$ dengan kualifikasi baik (B). Namun demikian, masih perlu diadakan perbaikan dalam beberapa hal agar deskriptor yang ada dapat dimaksimalkan dalam pembelajaran

\section{Hasil belajar siswa}

Hasil belajar yang akan dicapai dalam pembelajaran pembagian pecahan biasa dengan pendekatan konstruktivisme terbagi menjadi tiga ranah, yaitu: 1) Ranah Kognitif. Dari 21 siswa sebanyak 13 siswa telah mencapai KKM yang ditentukan dan 8 siswa lainnya masih berada di bawah $\mathrm{KKM}$, dengan skor tertinggi 100 dan skor terendah yang diperoleh siswa 40 . Skor yang diperoleh adalah 70,48\% dengan kualifikasi baik (B); 2) Ranah Afektif. Dari 21 siswa hanya 5 siswa saja yang mencapai KKM yang ditentukan dan 16 siswa lainnya masih berada di bawah KKM, dengan skor tertingginya adalah 91,67 dan skor terendahnya 41,67. Rata-rata skor yang diperoleh adalah 77,62\% dengan kualifikasi baik (B); 3) Ranah Psikomotor. Dari 21 siswa hanya 8 siswa saja yang mencapai KKM yang ditentukan dan 13 siswa lainnya masih berada di bawah KKM, dengan skor tertingginya adalah 83,33 dan skor terendahnya 41,67 . Skor yang diperoleh adalah $76,19 \%$ dengan kualifikasi baik (B).

Berdasarkan hasil belajar tiga ranah di atas diketahui bahwa pembelajaran pembagian pecahan biasa dengan pendekatan konstruktivisme pada pertemuan 2 siklus I ini masih memiliki kekurangan yang harus diperbaiki pada siklus berikutnya.

\section{Refleksi}

Refleksi dilakukan setelah pengamatan dan analisis pelaksanaan pembelajaran siklus I pertemuan 2. Hasil belajar siswa ranah kognitif pada siklus I pertemuan 2 masih di bawah nilai KKM yang telah ditetapkan yaitu 70,48\%. Pada ranah afektif mulai terdapat peningkatan dibandingkan dengan hasil belajar afektif siswa pada pembelajaran siklus I pertemuan 1. Banyak siswa yang terlihat mulai aktif dalam melakukan tanya jawab dengan guru, namun sebagian siswa masih ada yang tidak serius dalam melakukan pembelajaran dan kurang menghargai temannya. Hasil belajar ranah afektif memperoleh rata-rata nilai 77,62\%.

Selanjutnya pada ranah psikomotor terlihat peningkatan meskipun masih ada siswa yang kesulitan saat menjawab pertanyaan yang diberikan, membangun pemahaman mengenai konsep baru yang diberikan, ataupun dalam mengaplikasikan pemahaman baru tersebut dalam bentuk penyelesaian soal-soal. Hasil belajar pada ranah psikomotor ini memperoleh rata-rata $76,16 \%$.

Secara keseluruhan diperoleh rata-rata hasil belajar siswa pada siklus I pertemuan 2 ini adalah 74,75\%. Berdasarkan dari hasil tersebut dapat disimpulkan bahwa pembelajaran pembagian pecahan biasa dengan pendekatan konstruktivisme pada siklus I pertemuan 2 mulai mengalami peningkatan. Namun demikian, berbagai perbaikan juga masih perlu dilakukan demi tercapainya hasil belajar yang maksimal. Oleh sebab itu, peneliti merasa perlu untuk melanjutkan penelitian ini ke siklus II.

\section{Siklus II Pertemuan 1 \\ Perencanaan}

Sebelum melaksanakan pembelajaran pembagian antara pecahan dengan bilangan asli pada pertemuan 2 siklus I ini, peneliti juga merancang perencanaan pelaksanaan pembelajaran yang pada dasarnya sama dengan perencanaan pembelajaran pada siklus I pertemuan 1 dan pertemuan 2. Siklus II merupakan perbaikan dari pembelajaran siklus I. Hal ini dilakukan berdasarkan refleksi pada siklus I pertemuan 1 dan pertemuan 2.

\section{Pelaksanaan}

Pelaksanaan pembelajaran siklus II pertemuan 2 ini dilaksanakan pada Jumat, 03 Mei 2019 pukul 11.03-12.15 WIB dengan jumlah 21 siswa. Pembelajaran dilakukan dengan tiga tahap yaitu kegiatan awal, kegiatan inti, dan kegiatan akhir sesuai dengan RPP yang telah dibuat, dapat dilihat pada lampiran.

\section{Kegiatan Awal}

Kegiatan mengkondisikan kelas, berdo'a, mengabsen siswa, apersepsi tentang pembelajaran sebelumnya, dan menyampaikan tujuan pembelajaran pembagian antara dua pecahan biasa. 


\section{Kegiatan Inti}

Kegiatan inti mencakup Eksplorasi, tahap pertama. Pada tahap ini siswa diberikan kesempatan untuk mengemukakan pengetahuan awal mengenai konsep yang akan dipelajari, yaitu: a) siswa dan guru bertanya jawab tentang pembagian pecahan yang diketahui, b) siswa diberi kesempatan untuk mengkomunikasikan pemahaman mereka tentang pembagian pecahan, c) Siswa menyebutkan contoh masalah tentang pembagian pecahan yang sering ditemui dalam kehidupan sehari-hari, d) Siswa dan guru bertanya jawab tentang contoh bentuk lain pembagian pecahan biasa. Siswa diarahkan pada contoh pembagian antara dua pecahan biasa yang sering ditemui.

Elaborasi, tahap kedua. Pada tahap ini siswa akan menemukan konsep baru yang dipelajari. Kegiatannya berupa: a) siswa duduk dalam kelompok belajar yang dibagi guru. Kelompok belajar dibagi menjadi 4 kelompok yang heterogen. Masing-masing kelompok dibagikan LKS mengenai pembagian antara dua pecahan biasa dan media berupa kertas origami. b) Siswa mengerjakan soal yang ada pada LKS sesuai dengan petunjuk dan media yang disediakan. Masing-masing siswa dalam kelompoknya diberi kesempatan untuk menemukan hasil permasalahan/soal yang ada pada LKS. c) Siswa menggambarkan pada LKS hasil pembagian antara dua pecahan biasa yang diperoleh dari penggunaan media, dan d) siswa mendiskusikan hasil kerja mereka di dalam kelompok. Kemudian siswa akan menulis laporan terhadap hasil kerjanya berupa gambar dan hasil LKS mereka.

Tahap ketiga. Di tahap ini siswa dibimbing membangun sendiri pemahaman baru mereka tentang konsep pembagian antara dua pecahan biasa. Kegiatan yang dilakukan: a) Masing-masing perwakilan kelompok melaporkan hasil kerja kelompok, b) kelompok lain diberikan kesempatan untuk menanggapi laporan yang disampaikan, dan c) guru bertugas mengontrol kelancaran diskusi. Konfirmasi dengan kegiatannya yaitu guru memberikan penguatan terhadap kerja kelompok. Dengan adanya penguatan dari guru, siswa dapat memantapkan pemahaman baru mengenai cara melakukan pembagian antara dua pecahan biasa.

Tahap keempat. Pada tahap ini siswa mengaplikasikan pemahaman dari konsep baru yang telah dibangunnya berupa pemberian contoh soal lain mengenai pembagian antara dua pecahan biasa. Kegiatan pada tahap ini adalah a) siswa mengerjakan contoh soal lain tentang pembagian antara dua pecahan biasa yang diberikan guru, b) siswa dan guru membahas secara bersama contoh soal pembagian antara dua pecahan biasa yang diberikan guru, dan c) guru melakukan refleksi berupa tanya jawab bersama siswa mengenai cara meyelesaikan pembagian antara dua pecahan biasa.

\section{Kegiatan Akhir}

Pada kegiatan akhir ini, a) siswa dengan bimbingan guru menyimpulkan materi pembelajaran tentang pembagian antara dua pecahan biasa, b) siswa diberikan tindak lajut berupa soal-soal latihan yang harus dikerjakan secara individu. Soal-soal ini merupakan penilaian individu untuk pemahaman siswa terhadap materi.

\section{Pengamatan}

\section{Rencana pelaksanaan pembelajaran}

Berdasarkan pengamatan ini, dalam pembelajaran yang dilakukan telah terlaksana 15 deskriptor dari total maksimal 16 deskriptor yang telah. Dari penilaian tersebut diperoleh persentase 93,75\% dengan kualifikasi sangat baik (SB). Dengan demikian dapat disimpulkan bahwa aktivitas guru dalam pembelajaran sudah terlaksana dengan maksimal.

\section{Aktivitas siswa selama proses pembelajaran}

Berdasarkan pengamatan terhadap aktivitas siswa dalam pembelajaran hanya 15 deskriptor yang terlaksana dari total maksimal 16 deskriptor yang telah. Dari penilaian tersebut diperoleh persentase 93,75\% dengan kualifikasi sangat baik (SB). Dengan demikian dapat disimpulkan bahwa aktivitas siswa dalam mengikuti pembelajaran telah maksimal.

\section{Hasil belajar siswa}

Hasil belajar yang dicapai dalam pembelajaran pembagian pecahan biasa dengan pendekatan konstruktivisme terbagi menjadi tiga ranah, yaitu ranah kognitif, afektif, dan psikomotor. Hasil belajar ketiga ranah tersebut yang telah dicapai pada siklus ini dijelaskan sebagai berikut: 1) Ranah Kognitif. Dari 21 siswa sebanyak 19 siswa telah mencapai KKM yang ditentukan dan hanya 2 siswa yang masih berada di bawah KKM, dengan skor tertinggi 100 dan skor terendah yang diperoleh siswa 60. Skor yang diperoleh adalah 85,24\% dengan kualifikasi sangat baik (SB); 2) Ranah Afektif. Dari 21 siswa hanya 5 siswa saja masih berada dibawah KKM yang ditentukan dan 16 siswa lainnya telah mencapai KKM, dengan skor tertingginya adalah 91,67 dan skor terendahnya 58,33. Skor yang diperoleh adalah 92,38\% dengan kualifikasi sangat baik (SB); 3) Ranah 
Psikomotor. Dari 21 siswa diperoleh hasil bahwa sebanyak 17 siswa telah mencapai KKM dan 4 orang masih berada di bawah KKM, dengan skor tertingginya adalah 91,67 dan skor terendahnya 58,33. Skor yang diperoleh adalah $90,95 \%$ dengan kualifikasi sangat baik (SB).

Berdasarkan hasil belajar pada tiga ranah di atas dapat diketahui bahwa pembelajaran pembagian pecahan biasa dengan pendekatan konstruktivisme pada siklus II pertemuan 1 ini telah mencapai peningkatan hasil belajar siswa. Sehingga tidak diperlukan lagi penelitian pada pertemuan selanjutnya.

\section{Refleksi}

\section{Rencana Pelaksanaan Pembelajaran}

Berdasarkan lembar penilaian RPP yang diamati dan dinilai oleh guru kelas V disimpulkan bahwa pembelajaran pembagian pecahan biasa menggunakan pendekatan konstruktivisme telah terlaksana dengan maksimal. Hal ini terbukti dengan adanya peningkatan pada skor yang diperoleh yaitu $96,43 \%$ dengan kualifikasi sangat baik (SB). Berdasarkan dari hasil tersebut dapat disimpulkan bahwa deskriptor yang terdapat pada RPP telah maksimal dilaksanakan.

\section{Pelaksanaan aktivitas guru}

Berdasarkan hasil pengamatan dan analisis tersebut dapat diketahui bahwa dalam pelaksanaan pembelajaran pembagian pecahan biasa pada siklus II pertemuan 1 ini telah terlaksana dengan baik. Hampir semua deskriptor yang direncanakan telah terlihat dalam aktivitas guru. Hal ini dapat dilihat dari skor $93,75 \%$ yang diperoleh dengan kualifikasi sangat baik (SB).

\section{Pelaksanaan aktivitas siswa}

Sama halnya dengan aktivitas guru dalam pembelajaran, aktivitas siswa di dalam pembelajaran pembagian pecahanbiasa pada siklus II pertemuan 1 juga telah memberikan peningkatan yang signifikan. Hal ini terlihat dari persentase skor yang diperoleh yaitu $93,75 \%$ dengan kualifikasi sangat baik (SB).

\section{Hasil belajar siswa}

Hasil belajar siswa pada siklus II pertemuan 1 telah memperlihatkan peningkatan hasil belajar pada pembelajaran pembagian pecahan di kelas VI UPT SDN 08 Lunang. Hal ini disimpulkan setelah melihat hasil belajar pada tiga ranah. Hasil belajar pada ranah kognitif didapatkan hasil pembelajaran dengan skor $85,24 \%$ dengan kualifikasi sangat baik (SB). Selanjutnya pada ranah afektif diperoleh skor $92,38 \%$ dengan kualifikasi sangat baik (SB). Ranah yang ketiga yaitu ranah psikomotor yang mencapai $90,95 \%$ dengan kualifikasi sangat baik (SB).

\section{Pembahasan}

\section{Siklus I}

\section{Perencanaan}

Hal-hal yang perlu diperhatikan dan diperbaiki tersebut adalah a) rumusan tujuan pembelajaran harus mengandung perilaku hasil belajar (kognitif, afektif, psikomotor), b) pemilihan materi ajar disesuaikan dengan tingkat pemahaman siswa, c) pemilihan materi ajar disesuaikan dengan lingkungan siswa, d) pengorganisasian materi disesuaikan dengan alokasi waktu, e) cakupan materi yang diberikan lebih luas, f) pemilihan sumber/media pembelajaran yang sesuai dengan tujuan pembelajaran, g) pemilihan sumber/media pembelajaran yang sesuai dengan lingkungan siswa, h) teknik pembelajaran sesuai dengan pendekatan, i) tahap-tahap pembelajaran sesuai dengan alokasi waktu, $\mathrm{j}$ ) tahap-tahap pembelajaran jelas dan terperinci. Berdasarkan pangamatan dan analisis observer, diperoleh hasil penilaian RPP siklus 1 dengan persentase $92,86 \%$ dengan kualifikasi cukup.

\section{Pelaksanaan}

Berdasarkan dari perencanaan yang dirancang, pelaksanaan pembelajaran dilaksanakan dua kali pertemuan yaitu 4x35 menit (140 menit). Pelaksanaan pembelajaran pada siklus I dibagi menjadi tiga tahap yaitu: kegiatan awal, kegiatan inti, dan kegiatan akhir. Hasil penilaian kegiatan guru pada pertemuan pertama memperoleh persentase $62,5 \%$ dan pertemuan kedua memperoleh persentase $75 \%$, sehingga diperoleh ratarata $68,75 \%$ dengan kualifikasi cukup. Sedangkan pada penilaian kegiatan siswa pada pertemuan pertama memperoleh persentase $62,5 \%$ dan pada pertemuan kedua memperoleh persentase $75 \%$ dan diperoleh ratarata $68,75 \%$ dengan kualifikasi cukup.

\section{Hasil belajar}

Dalam hasil belajar tersebut dapat dilihat dari tiga aspek yaitu, aspek kognitif, aspek afektif dan, aspek psikomotor. Pada pertemuan 1 nilai rata-rata hasil belajar aspek kognitif 62,86 aspek afektif 55,16, aspek psikomotor 58,73 serta nilai rata-rata hasil belajar 60,06. Dan pada pertemuan 2 hasil belajar siswa mengalami peningkatan namun belum mencapai kriteria yang diinginkan, berikut merupakan hasil belajar siswa dilihat 
dari aspek kognitif 70,48, aspek afektif 77,62, dan aspek psikomotor 76,19 serta rata-rata hasil belajar 66,22. Jika dilihat dari rekapitulasi keberhasilan siswa pada siklus I diperoleh gambaran bahwa rata-rata keberhasilan siswa pada siklus I untuk ketiga aspek adalah 63,14 dengan ketuntasan belajar 23,18\%. Ini menunjukkan siklus I belum mencapai ketuntasan yang diharapkan yaitu $75 \%$ siswa mencapai KKM yang telah ditetapkan yaitu $\geq 70$. Untuk itu perlu diadakan tindakan dan dilanjutkan pada siklus II.

\section{Siklus II}

\section{Perencanaan}

Rencana pelaksanaan pembelajaran yang dirancang pada siklus II sudah dinyatakan pada kualifikasi sangat baik walau masih belum maksimal, karena masih ada kegiatan yang belum terlaksana. Terlihat pada aspek kelengkapan instrumen pembelajaran yaitu soal yang belum disertai dengan pedoman skor yang jelas dan lengkap. Berdasarkan pangamatan dan analisis observer, diperoleh hasil penilaian RPP siklus II dengan persentase 92,86\% dengan kualifikasi sangat baik (SB).

\section{Pelaksanaan}

Hasil penilaian kegiatan guru pada pertemuan pertama memperoleh persentase 93,75\% dengan kualifikasi sangat baik. Sedangkan pada penilaian kegiatan siswa pada pertemuan pertama memperoleh persentase 93,75 $\%$ dengan kualifikasi sangat baik.

\section{Hasil belajar}

Dalam hasil belajar tersebut dapat dilihat dari tiga aspek yaitu, aspek kognitif, aspek afektif dan, aspek psikomotor. Nilai rata-rata hasil belajar aspek kognitif 85,24 . Nilai rata-rata hasil belajar aspek afektif 92,38 dan 93,75 untuk nilai hasil belajar aspek psikomotor.

Jika dilihat dari rekapitulasi keberhasilan siswa pada siklus II diperoleh nilai rata-rata untuk ketiga aspek adalah 89,52 dengan ketuntasan belajar 85,71 \%. Ini menunjukkan siklus II telah mencapai ketuntasan yang diharapkan yaitu $75 \%$ siswa mencapai KKM yang telah ditetapkan yaitu $\geq 70$. Maka dari itu, penelitian dicukupkan pada siklus II dengan 1 kali pertemuan.

\section{Simpulan}

Berdasarkan dari hasil paparan pada data dan analisis, maka peneliti dapat membuat kesimpulan dari penelitian bahwa pembelajaran pembagian pecahan biasa dengan pendekatan konstruktivisme sebagai berikut: 1) Perencanan pembelajaran pembagian pecahan biasa dengan pendekatan konstruktivisme dapat meningkatkan hasil belajar siswa kelas VI UPT SDN 08 Lunang . Dari segi perencanaan, siklus I memperoleh persentase 92,86 \% dengan kualifikasi baik sekali. Pada siklus II mengalami peningkatan menjadi 96, $43 \%$ dengan kualifikasi baik sekali; 2) Pelaksanaan pembelajaran pembagian pecahan biasa dengan pendekatan konstruktivisme dapat meningkatkan hasil belajar siswa kelas VI UPT SDN 08 Lunang. Hal ni dapat dilihat dari hasil peniaian terhadap aktivitas guru maupun aktivitas siswa. Dari segi pelaksanaan, pada siklus I aktivitas guru memperoleh 68,75\% dengan kualifikasi cukup, siklus II memperoleh persentase 93,75\% dengan kualifikasi baik sekali. Dan pada aktivitas siswa siklus I memperoleh persentase 68,75\% dengan kualifikasi cukup, siklus II mengalami peningkatan menjadi 93,75\% dengan kualifikasi baik sekali; 3) Hasil belajar pembelajaran pembagian pecahan biasa dengan pendekatan konstruktivisme mengalami peningkatan secara bertahap dari siklus I hingga siklus II. Pada siklus I dengan nilai rata-rata 63,14 dengan ketuntasan belajar 23,18 \%. Pada siklus II hasil belajar siswa mengalami peningkatan dengan nilai rata-rata 89,52 dengan ketuntasan belajar 85,71\%.

\section{Referensi}

A. Pribadi, Benny. (2009). Model Desain Pembelajaran. Jakarta: Dian Rakyat

Ambarita, Alben. (2006). Manajemen Pembelajaran. Jakarta: Depdiknas.

Arikunto, Suharsimi.(1993). Prosedur penelitian suatu pendekatan praktek. Jakarta: Rineka cipta

Budiningsih, Asri. (2005). Belajar dan Pembelajaran. Jakarta: Rineka Cipta.

Dahar, R.W. (2011). Teori-Teori Belajar. Jakarta: Erlangga.

Dalais, Mursal. (2007). Kiat Mengajar Matematika di Sekolah Dasar. Padang: UNP Press.

Harun, Mardiah.dkk. (2009. Matematika Pemahaman dan Pembelajaran di Sekolah Dasar. Padang: Sukabina Press.

Heruman. (2007). Model Pembelajaran Matematika di Sekolah Dasar. Bandung: Rosda 
Kunandar. (2008). Langkah Mudah Penelitian Tindakan Kelas sebagai Pengembangan Profesi Guru. Jagakarsa: Rajawali Pers

Lufri. (2004). Konsep Teori, Pendekatan, Metode, dan Strategi dalam Pembelajaran. Padang: Jurusan Biologi FMIPA UNP

Oemar Hamalik. (1993). Proses Belajar Mengajar. Jakarta:Bumi Aksara.

Paul Suparno. (1997). Filasafat Konstruktivisme Dalam Pendidikan. Yogyakarta: Pustaka Filsafat.

Purwanto, M. Ngalim. (1996). Psikologi Pendidikan. Bandung: Remaja Rosdakarya. .

Riyanto, Yatim. (2009). Paradigma Baru Pembelajaran: Sebagai Referensi Bagi Guru/Pendidik dalam Implementasi Pembelajaran yang Efektif dan Berkualitas. Jakarta: Kencana.

Sanjaya, Wina. (2007). Strategi Pembelajaran Berorientasi Standar Proses Pendidikan. Jakarta: Kencana Prenada Media Group.

Slameto. (1995). Belajar dan Faktor-faktor yang Mempengaruhinya. Jakarta : Rineka Cipta.

Slavin, Roberth, E. (1994). Educational Psychology: Theory and Practice. Foorth Edition: Jhon Hopkins University.

Sudjana, Nana. (2011). Penilaian Hasil Proses Belajar Mengajar. Bandung: Remaja Rosdakarya.

Sugiyono. (2012). Metode Penelitian Pendidikan. Bandung: Alfabeta.

Sukajati. (2008). Penelitian Tindakan Kelas. Yogyakarta: PPPPTK Matematika

Sumiati dan Asra. (2007). Metode Pembelajaran. Bandung: CV. Wacana Prima.

Suyono dan Hariyanto. (2011). Belajar dan Pembelajaran. Bandung: Remaja Rosdakarya Offset 